\title{
Distribution and Survival of Pseudomonas sp. on Italian Ryegrass and Curly Dock in Georgia
}

Bhabesh Dutta and Ronald D. Gitaitis, Department of Plant Pathology, University of Georgia, Coastal Plain Experiment Station, Tifton 31793-0748; Theodore M. Webster, Crop Protection and Management Research Unit, United States Department of AgricultureAgricultural Research Service, Tifton, GA 31793-0748; Hunt Sanders, Samuel Smith, and David B. Langston, Jr., Department of Plant Pathology, University of Georgia, Coastal Plain Experiment Station, Tifton

\begin{abstract}
Dutta, B., Gitaitis, R. D., Webster, T. M., Sanders, H., Smith, S., and Langston, D. B., Jr. 2014. Distribution and survival of Pseudomonas sp. on Italian ryegrass and curly dock in Georgia. Plant Dis. 98:660-666.

Yellow bud, caused by Pseudomonas sp., is an emerging bacterial disease of onion. A polymerase chain reaction assay based on the coronafacate ligase $(c f l)$ and HrpZ genes was used to detect initial suspected bacteria on weeds. Growth on an agar medium, ability to cause a hypersensitive response in tobacco, pathogenicity on onion, and sequence analysis of $16 \mathrm{~S}$ ribosomal RNA and $c f l$ genes were used to confirm the identity of Pseudomonas sp. recovered from 10 asymptomatic weed species in the Vidalia onion-growing zone (VOZ) of Georgia. Among the weeds identified as epiphytic hosts for Pseudomonas sp., Italian ryegrass (Lolium multiflorum) and curly dock (Rumex crispus) were prominent because $\geq 73 \%$ of the samples from five sample sites were positive for the bacterium. These weeds are commonly found throughout Georgia and, thus, were selected to assess their role in yellow bud epidemiology. Samples of the two weed species were collected from sites along the perimeter of and within the VOZ $(n=5$ sites) during late June, August, and September 2012 and 2013, which represented the time interval between onion growing seasons. Samples

( $n=10$ /weed species/site) were collected and processed for bacterial detection as described above. In June (2012 and 2013), Pseudomonas sp. was detected from Italian ryegrass and curly dock in 100 and $40 \%$ of the sample sites, respectively. During the months of August and September (2012), the bacterium was recovered from Italian ryegrass in 60 and $10 \%$ of the sample sites, respectively; whereas, in August (2013), Pseudomonas sp. was recovered from $40 \%$ of the sample sites. However, the bacterium was not recovered from any of the sites in September (2013). In contrast, during August and September (2012), Pseudomonas sp. was recovered from curly dock in 20 and $80 \%$ of the sample sites, respectively. Similarly, in August and September (2013), the bacterium was detected from 40 and $100 \%$ of the sample sites, respectively. These data demonstrated that the Pseudomonas sp. responsible for yellow bud can survive as an epiphyte on Italian ryegrass and curly dock between onion crops. Furthermore, using artificially infested onion seed, we demonstrated that Pseudomonas sp. can be transmitted through contaminated seed.
\end{abstract}

Yellow bud (YB) is an emerging onion (Allium cepa L.) disease that has potential to severely affect Vidalia onion production. This disease was first observed in Georgia in 2007 and has since been spreading throughout the Vidalia onion-growing zone (VOZ) in Georgia (9). However, to the best of our knowledge, this disease has not been reported elsewhere. Symptoms of YB include intense chlorosis in emerging leaves and severe blight in the older leaves. In time, YB leads to stand loss and reduced bulb size, and may create possible avenues of ingress for secondary, soft rot organisms (9). The disease has also been observed in onion seed beds; thus, infected transplants could be widely dispersed to areas throughout the VOZ or elsewhere. Occurrence of YB in seedbeds may be an indication that the pathogen could be seedborne; however, seed infestation has not been investigated to date.

The causal agent is a gram-negative, rod-shaped, aerobic bacterium that possesses all the phenotypic characteristics of Pseudomonas syringae van Hall LOPAT group Ia of Lelliott et al. (12). It produces levan; is negative for oxidase, potato rot, and arginine dihydrolase; and produces a hypersensitive reaction in tobacco. Like some other species sharing these traits, YB strains have the ability to produce a chlorosis-inducing toxin, coronatine (15). This bacterium also belongs to the family of HrpZ group IV of the genus $P$ seudomonas along with $P$. coronafaciens pv. atropurpurea, $P$. coronafaciens pv. porri, $P$. coronafaciens pv. striafaciens, and $P$. coronafaciens pv. garcea (11). However, unlike other members of

Corresponding author: B. Dutta, E-mail: bhabesh@uga.edu

Accepted for publication 2 December 2013.

http://dx.doi.org/10.1094/PDIS-10-13-1077-RE

(c) 2014 The American Phytopathological Society
LOPAT group Ia and HrpZ group IV, the YB bacterium is nonfluorescent when grown on King's medium $\mathrm{B}$. The YB bacterium is possibly a pathovar of $P$. coronafaciens (because it is host specific) but the identity of the species is still being investigated and, for this article, Pseudomonas sp. is used to refer to the YB bacterium.

Currently, we lack basic information on the possible sources of inoculum, survival and spread of the pathogen, and biology of bacterial infection. The identification of inoculum sources for the disease could result in the development of management practices that will reduce disease severity and minimize economic losses. In this research, we identified two weed species as a potential local source of inoculum, and assessed whether the bacterium could survive on these weeds within and around the VOZ in Georgia between onion harvest in the spring and the seeding of next year's crop in the fall. Onion plants are grown as a winter crop in Georgia. The seedbeds are planted in September to October; transplants are set in November to January and harvested in April to May. This means that the pathogen has to overseason between the onion harvest in May and onion seeding in September, or be reintroduced each year.

The objectives of this study were to (i) determine whether any weed species in the VOZ harbored epiphytic populations of the YB bacterium, (ii) determine the presence of the YB bacterium on identified weed species within and outside of the VOZ during the overseasoning period between onion crops in two consecutive years (2012 and 2013), and (iii) evaluate the ability of artificially infested onion seed to transmit the pathogen to the seedlings.

\section{Materials and Methods}

Weed samples. In 2012, representative weed species were collected from the perimeter of the onion fields ( $\mathrm{O}$ sites) that had significant levels of $\mathrm{YB}$, from areas that were left fallow in the current season but had been traditionally used for growing onion in 
the recent past ( $\mathrm{F}$ sites), or from fields which were never used for onion production $(\mathrm{N})$. Weed samples from a fallow field in Tattnall County (where YB was originally reported in 2007) were also included in the preliminary survey. Weed samples $(n=10 /$ species/ location) were collected from the edge of fields. All weed samples were stored in plastic bags and transported on ice to the laboratory in Tifton, where they were stored at $4^{\circ} \mathrm{C}$ and identified to species.

Processing of weed samples. Weed leaves and stems $(3 \mathrm{~g})$ were placed in $20 \mathrm{ml}$ of phosphate-buffered saline (PBS; $0.05 \mathrm{M}$ $\mathrm{K}_{2} \mathrm{HPO}_{4}-\mathrm{KH}_{2} \mathrm{PO}_{4}, \mathrm{pH} 7.0$, and $0.85 \% \mathrm{NaCl}$ ) and were shaken overnight at approximately $150 \mathrm{rpm}$ on a rotary shaker at $25^{\circ} \mathrm{C}$. After incubation, 2.0- $\mathrm{ml}$ aliquots were removed and divided into two fractions of $1.0 \mathrm{ml}$ each, which were placed in separate, $1.5-\mathrm{ml}$ sterile microcentrifuge tubes. Each sample was centrifuged for 5 min at 5,000 $\times g$ (Allegra 25R; Beckman Coulter) and the supernatant was decanted, leaving a pellet, which was then resuspended in $0.1 \mathrm{M}$ PBS

Identification of Pseudomonas sp. (the YB bacterium). Total microbial genomic DNA was extracted from the 1-ml fraction using an UltraClean Microbial DNA Kit (MO BIO) according to the manufacturer's instructions. Extracted DNA was subjected to SYBR-green based real-time polymerase chain reaction (PCR) using coronafacate ligase ( $c f l$ gene-specific primers (4). This gene encodes an enzyme that catalyzes the coupling reaction of coronafacic acid and coronamic acid for the biosynthesis of coronatine toxin (3). For real-time PCR, $5 \mu \mathrm{l}$ of DNA was amplified in $25 \mu \mathrm{l}$ of PCR master mix containing $12.5 \mu \mathrm{l}$ of SsoFast EvaGreen Supermix (Bio-Rad Laboratories Inc.) and $1 \mu \mathrm{l}$ each of $25 \mu \mathrm{M}$ primers CFL F 5'-GGCGCTCCCTCGCACTT-3' and CFL R 5'-GGTATT GGCGGGGGTGC-3' (4). Real-time PCR was carried out in a Cepheid Smart Cycler using the following thermal profile: denaturation at $95^{\circ} \mathrm{C}$ for 3 min and 35 cycles each of denaturation at $95^{\circ} \mathrm{C}$ for $30 \mathrm{~s}$, annealing at $63^{\circ} \mathrm{C}$ for $30 \mathrm{~s}$, and extension at $72^{\circ} \mathrm{C}$ for $30 \mathrm{~s}$. Samples with cycle threshold values less than 35 were considered positive for the $c f l$ gene. This approach was adopted because Pseudomonas sp. has the ability to produce a chlorosisinducing phytotoxin (coronatine) and Gitaitis et al. (9) reported the presence of a coronatine biosynthesis gene $(c f l)$ in this bacterium. Hence, initial screening for the YB bacterium was based on the presence or absence of this gene. However, this gene is also present in other fluorescent pseudomonads such as $P$. syringae pv. maculicola, $P$. syringae pv. glycinea, $P$. syringae pv. morsprunorum, $P$. syringae pv. tomato, $P$. coronafaciens pv. atropurpurea, and $P$. coronafaciens pv. coronafaciens $(2,3,14-16,20)$.

Additionally, microbial DNA samples from weed washes were also subjected to HrpZ group IV-based conventional PCR assay (11). For PCR, $2 \mu \mathrm{l}$ of bacterial DNA was amplified in $25 \mu \mathrm{l}$ of PCR master mix containing $10 \mathrm{mM}$ Tris- $\mathrm{HCl}(\mathrm{pH} \mathrm{9.0),} 50 \mathrm{mM}$ $\mathrm{KCl}, 0.1 \%$ Triton $\mathrm{X}-100,1.5 \mathrm{mM} \mathrm{MgCl} 2,0.2 \mathrm{mM}$ each nucleotide (dATP, dCTP, dGTP, and dTTP), $10 \mu \mathrm{M}$ each HrpZ group IV-specific primers P1 (5'-ATGCTCGCAAAATCGATGGC-3') and P2 (5'-TGACTGGCCGTATTGCCATT-3'), and 1 unit of Taq DNA polymerase (Promega Corp.) per reaction. DNA amplification was carried out in a Mastercycler Gradient programmable thermal cycler (Eppendorf). The amplification conditions included denaturation at $94^{\circ} \mathrm{C}$ for $2 \mathrm{~min} ; 30$ cycles of denaturation at $94^{\circ} \mathrm{C}$ for $30 \mathrm{~s}$, annealing of primers at $60^{\circ} \mathrm{C}$ for $30 \mathrm{~min}$, and elongation at $72^{\circ} \mathrm{C}$ for $2 \mathrm{~min}$; plus one final extension step of $10 \mathrm{~min}$ at $72^{\circ} \mathrm{C}$. For the above-stated PCR reactions, an internal PCR control was included to test for PCR inhibition in samples that yielded negative results. Pseudomonas sp. (Y-2) genomic DNA at $10 \mathrm{ng} / \mu \mathrm{l}$ was added to the five separate DNA samples isolated from leaf washes and assayed by both real-time PCR with $c f l$ gene-specific primers and conventional PCR with HrpZ group IV-specific primers, as described above.

From the remaining $1.0-\mathrm{ml}$ fraction, $0.1-\mathrm{ml}$ aliquants were $10-$ fold serially diluted in $0.9 \mathrm{ml}$ of PBS and $0.1-\mathrm{ml}$ aliquants from the resulting suspension were spread-plated on nutrient agar (NA) supplemented with $0.5 \%$ yeast extract $(\mathrm{NA}+)$. After incubation for $48 \mathrm{~h}$ at $28^{\circ} \mathrm{C}$, agar plates were evaluated for the presence of creamy white, flat colonies. Five random colonies per plate displaying these characteristics were evaluated by levan production, oxidase reaction, potato rot, arginine dihydrolase activity, and hypersensitivity reactions on tobacco (LOPAT) and ice-nucleation tests (8). Further confirmation of the YB bacterium was carried out by PCR amplifying 16S ribosomal (r)RNA (21) and $c f l$ genes from at least three colonies per plate (identified as +---+ in LOPAT test and were ice-nucleating) and partial DNA sequencing. Bacterial DNA $(2 \mu \mathrm{l})$ was PCR amplified with 16S rRNA primers (fD1 AGAGTT TGATCCTGGCTCAG and rD1 AAGGAGGTGATCCAGCC) (21) and $c f l$-specific primers, separately, in $25 \mu \mathrm{l}$ of PCR master mix containing $10 \mathrm{mM}$ Tris- $\mathrm{HCl}$ ( $\mathrm{pH} 9.0), 50 \mathrm{mM} \mathrm{KCl}, 0.1 \%$ Triton X$100,1.5 \mathrm{mM} \mathrm{MgCl} 2,0.2 \mathrm{mM}$ each nucleotide (dATP, dCTP, dGTP, and dTTP), $10 \mu \mathrm{M}$ each primer, and 1 unit of Taq DNA polymerase (Promega Corp.) per reaction. DNA amplification was carried out in a Mastercycler Gradient programmable thermal cycler (Eppendorf). For 16S rRNA primers, amplification conditions included an initial denaturation at $94^{\circ} \mathrm{C}$ for $180 \mathrm{~s} ; 33$ cycles of denaturation at $94^{\circ} \mathrm{C}$ for $45 \mathrm{~s}$, annealing of primers at $56^{\circ} \mathrm{C}$ for $1 \mathrm{~min}$, and elongation at $72^{\circ} \mathrm{C}$ for $2 \mathrm{~min}$; plus one final extension step of $5 \mathrm{~min}$ at $72^{\circ} \mathrm{C}$. The $c f l$ gene was amplified using similar PCR conditions as stated above. The PCR amplicon was purified using an affinity column (Wizard PCR Preps DNA Purification System; Promega Corp.) and sequenced by the Eurofins MWG Operon DNA sequencing facility. The amplified sequences were searched by the basic local alignment search tool (BLAST) and identity of the bacterium was confirmed with the matched sequence in the National Center for Biotechnology Information database.

Pathogenicity test on onion. Onion seedlings (cv. Century) were planted in 10-by-8-cm (diameter by height) pots (Hummert International) in a commercial potting mix (Sunshine LP5 Plug Mix; Sun Gro Horticulture Industries) in the greenhouse and maintained at 25 to $28^{\circ} \mathrm{C}$ and 70 to $75 \%$ relative humidity (RH) with a photoperiod of $12 \mathrm{~h}$ of light and $12 \mathrm{~h}$ of darkness. To determine pathogenicity, 15-day-old onion seedlings $(n=$ 10/isolate/experiment) were inoculated using a hypodermic syringe and needle to inject a $1.0-\mathrm{ml}$ suspension containing $1 \times 10^{8}$ $\mathrm{CFU} / \mathrm{ml}$ into the cavity of the leaf. Seedlings inoculated with PBS and a known YB strain (Y-2) served as negative and positive controls, respectively. Inoculated seedlings were evaluated for development of YB symptoms up to 15 days post inoculation.

Distribution and survival of Pseudomonas sp. (the YB bacterium) on weeds (Italian ryegrass and curly dock). The potential of YB bacteria overseasoning on the two most important identified weeds from the above experiments within and around the boundaries of the VOZ was investigated in two consecutive years (2012 and 2013). Sample areas included the following sites: west (W; Dodge County), southwest (SW; Coffee County), north (N; Burke County), and south (S; Pierce County). which were all just outside the VOZ (Fig. 1). An additional sample site was chosen within the VOZ that had a previous history of YB disease (Tattnall County). Sampling of the two weed species (curly dock and Italian ryegrass) was conducted during June, August, and September 2012 and 2013. Samples ( $n=10 /$ species/site) were collected and processed as described above. Identity of bacteria recovered was confirmed as described above. Additionally, recovered strains were tested for pathogenicity on onion as described above. Percentage of weed species positive for the YB bacterium from each sample site for each sampling period was recorded.

Seed transmission of Pseudomonas sp. Bacterial strains and inoculum preparation. Five YB strains originally isolated each from onion, Italian ryegrass, and curly dock ( $n=15$ strains) were grown on nutrient agar (NA+) medium for $48 \mathrm{~h}$ at $28^{\circ} \mathrm{C}$. Inoculum was prepared by transferring single colonies of each bacterial strain from 48-h-old cultures on NA+ medium to nutrient broth. This was followed by overnight incubation at $28^{\circ} \mathrm{C}$ on a rotary shaker (Innova; New Brunswick Scientific Co.) at $150 \mathrm{rpm}$. After overnight incubation, bacterial cultures were centrifuged at 5,000 $\times$ $g$ (Allegra 25R; Beckman Coulter) for $3 \mathrm{~min}$ and the supernatant was decanted, leaving a pellet of bacterial cells. The pellet was resuspended in $0.1 \mathrm{M}$ PBS and the concentration of bacterial cells 
was adjusted using a spectrophotometer (Spectronic 20; Bausch and Lomb) to an optical density of 0.3 at $600 \mathrm{~nm}$ (approximately 1 $\left.\times 10^{8} \mathrm{CFU} / \mathrm{ml}\right)$.

Generation of artificially inoculated seedlots. Fungicide-nontreated cv. Century onion seed $(n=10 \mathrm{~g} / \mathrm{strain} / \mathrm{lot})$ were placed in separate $250-\mathrm{ml}$ side-arm flasks containing $20 \mathrm{ml}$ of bacterial cell suspension (approximately $1 \times 10^{8} \mathrm{CFU} / \mathrm{ml}$ ). Five seedlots per bacterial strain were used in a single experiment and the experiment was repeated once. Seed (in bulk) were soaked in the inoculum suspension while being continuously agitated for $1 \mathrm{~h}$. Seed were subsequently removed from the cell suspension and air dried at approximately $25^{\circ} \mathrm{C}$ for $24 \mathrm{~h}$ in a laminar air-flow chamber. Seedlots treated in bulk with PBS served as negative controls. After air drying, seedlots were maintained in paper bags and stored for the short term ( 3 days) at $4^{\circ} \mathrm{C}$ until use.

Seedling grow-out assay. Inoculated or control seeds (PBS) $(n=$ $100 \mathrm{seed} / \mathrm{seedlot}$ ) were planted on two layers of blotter paper saturated with sterile water in transparent plastic boxes. Seed were maintained inside planter boxes for 18 days under conditions of $>90 \% \mathrm{RH}$ and $20^{\circ} \mathrm{C}$ under continuous fluorescent light. After 18 days, percent germination [(number of seedlings germinated/total number of seed planted $\times 100]$ and percent disease incidence [(number of seedlings with YB symptoms/total number of seedlings in the stand) $\times 100$ ] were determined for each seedlot. To confirm putative YB symptoms on seedlings, isolations were conducted from 10 symptomatic seedlings per lot. Isolations were made from small (approximately $4 \mathrm{~mm}^{2}$ ) pieces of leaf tissue that were excised and triturated in $100 \mu \mathrm{l}$ of PBS followed by streaking on $\mathrm{NA}+$ medium. After $48 \mathrm{~h}$ of incubation at $28^{\circ} \mathrm{C}$, cream-colored, round, flat colonies were tentatively identified as the YB bacterium. Confirmation of bacterial identity was achieved by extracting genomic DNA from two colonies per isolation, amplifying the $16 \mathrm{~S}$ rRNA and $c f l$ genes, and analyzing their sequences as described above. In addition, biochemical, physiological, and pathogenicity tests were conducted as described above. Seedlots that yielded at least one symptomatic seedling along with positive confirmation of bacterial identity were considered positive for seedborne transmission, and the percentage of positive lots was determined.

\section{Results}

In all, $100 \%$ of the weed wash samples that were spiked with the YB bacterium DNA were amplified with $c f l$ gene- and HrpZ group
IV-specific primers (data not shown), indicating that PCR inhibition did not occur. Preliminary screening for wild-type strains from weed washes by $c f l$ gene- and HrpZ group IV-specific primers identified 10 different weed species (Table 1) from three sample sites tested. Using PCR for amplification of the $c f l$ and HrpZ genes, the YB bacterium was detected in leaf washes of cutleaf geranium (Geranium dissectum L.), cutleaf evening primrose (Oenothera laciniata L.), and soybean (Glycine $\max$ L.) at the Candler County sampling site from $10, \leq 20$, and $\leq 26.7 \%$ of the samples, respectively. Presumptive colonies of the YB bacterium were isolated on NA+ plates of $3.3,16.7$, and $10 \%$ of the samples of cutleaf geranium, cutleaf evening primrose, and soybean, respectively (Table 1). Further identification by LOPAT and ice-nucleation tests showed that presumptive colonies produced levan; were negative for oxidase, potato rot, and arginine dihydrolase; produced the hypersensitive reaction in tobacco; and were ice-nucleation active. In addition, inoculation of suspect isolates on onion seedlings resulted in YB symptoms in $100 \%$ of the seedlings at 15 days after planting (Table 1).

Positive samples of Virginia pepperweed (Lepidium virginicum L.) and Carolina geranium (G. carolinianum L.) were detected only at the Toombs County sampling site, whereas the YB bacterium was isolated only from samples of black cherry (Prunus serotina L.) and Pennsylvania smartweed (Polygonum pensylvanicum L.) at the Tattnall County sampling site (Table 1 ). In total, $\leq 10 \%$ of the Virginia pepperweed and Carolina geranium samples were positive by cfl- and HrpZ group IV-based PCR assays. Bacterial isolates were recovered from weed washes from $6.7 \%$ of the samples for both weed species. In addition, $6.7 \%$ of bacterial isolates from each weed were pathogenic on onion upon inoculation (Table 1). Nearly 20 and $6.7 \%$ of the black cherry and Pennsylvania smartweed samples, respectively, were positive by PCR assays; however, presumptive bacterial colonies were isolated from only $10 \%$ of the samples for both weed species (Table 1). Inoculation of these isolates produced typical YB symptoms on onion seedlings.

Positive samples of wild mustard (Brassica sp.) were obtained from both Toombs and Tattnall Counties. In all, $\leq 3.3 \%$ of the samples were positive by $c f l$ - and HrpZ group IV-based PCR assays, and bacterial colonies were isolated from $3.3 \%$ of the weed samples (Table 1). Further identification by LOPAT, ice-nucleation, and pathogenicity on onion revealed that isolated colonies conformed to the Pseudomonas sp. that causes YB.

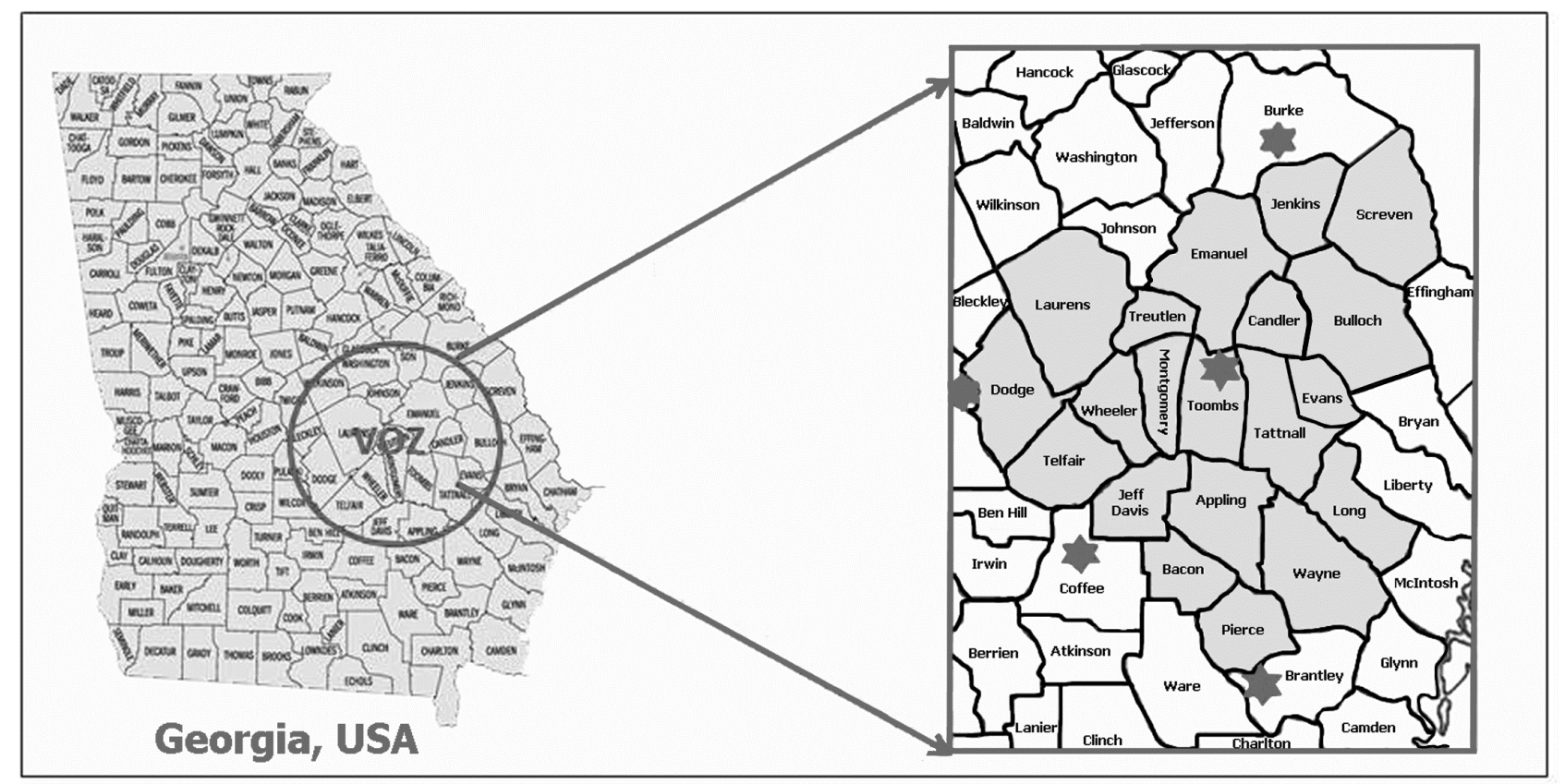

Fig. 1. Areas surveyed for Pseudomonas sp. (causal agent of yellow bud on onion) within and around the boundaries of the Vidalia onion-growing zone (VOZ; marked in circle). Survey sites (stars) are designated as north (N), south (S), southwest (SW), west (W), and a site within VOZ. 
Among the different weed species tested, the PCR assays detected the bacterium on the samples of Italian ryegrass (Lolium multiflorum L.; $\leq 80 \%$ ) and curly dock (Rumex crispus L.; $\leq 73.4 \%$ ) collected from all three locations (Table 1). Bacterial colonies were isolated from 70 and $73.4 \%$ of the samples of Italian ryegrass and curly dock, respectively, on NA+ medium. The isolated colonies had characteristics similar to those previously reported for YB strains (6). In all, 70 and $73.4 \%$ of the isolates from Italian ryegrass and curly dock, respectively, developed YB symptoms on onion seedlings upon inoculation.

The amplification of 16S rRNA and $c f l$ genes from at least two isolates per weed species were conducted and amplified products were sequenced and BLAST searched in GenBank. The nucleotide sequences of the $16 \mathrm{~S}$ rRNA gene $(750 \mathrm{bp})$ from weed isolates showed similarity to Pseudomonas sp. 7Y-1 (GenBank accession JF939841.1; percent identity $=99 \%$ ), Pseudomonas syringae pv. atropurpurea (GenBank accession AB001440.1; percent identity = 97\%), and Pseudomonas sp. IRG-1 strain (a YB strain from Italian ryegrass; GenBank accession KC786974.1; percent identity $=99 \%$ ).

The nucleotide sequences of the $c f l$ gene $(500 \mathrm{bp})$ from weed isolates displayed similarity to Pseudomonas sp. 7Y-1 (GenBank accession JF939842.1; percent identity $=100 \%$ ), Pseudomonas $\mathrm{sp}$.
IRG-1 strain (GenBank accession KC786976.1; percent identity = 100\%), and Pseudomonas sp. CD-1 strain (a YB strain from curly dock; GenBank accession KC786977.1; percent identity $=100 \%$ ).

Distribution and survival of Pseudomonas sp. on weeds (Italian ryegrass and curly dock) in 2012 and 2013. Because the YB bacterium was recovered from the Italian ryegrass and curly dock samples from all three sample sites and more than $73 \%$ of the weed samples harbored the bacterium, we studied the distribution and epiphytic survival of the YB bacterium using these two weeds as model systems. Bacterial survival was evaluated within and around the boundaries of the VOZ between onion growing seasons (June, August, and September) in 2012 and 2013.

In June 2012, the YB bacterium was recovered from Italian ryegrass from $100 \%$ of the sample sites. The percentages of Italian ryegrass samples harboring epiphytic populations of the YB bacterium from the $\mathrm{N}, \mathrm{W}, \mathrm{SW}$, and $\mathrm{S}$ sites and at the VOZ were 20,10, 20,50 , and $60 \%$ (Table 2), respectively. In contrast, during the same sampling period, bacterial isolates were not recovered from curly dock at the N, W, and SW sampling sites; however, curly dock samples from the S site and at the VOZ had 40 and $50 \%$ of the samples, respectively, test positive for the YB bacterium. In August 2012, Italian ryegrass samples were absent at the $\mathrm{W}$ and

Table 1. Sample sites, field history, polymerase chain reaction (PCR), isolation, and pathogenicity results of Pseudomonas sp. isolated from different weed species from the Vidalia onion zone of southern Georgia

\begin{tabular}{|c|c|c|c|c|c|c|c|c|c|c|}
\hline Sample & Common name & Latin binomial & Sample collection ${ }^{\mathrm{a}}$ & Positive $^{b}$ & Field $^{\mathrm{c}}$ & $N^{\mathrm{d}}$ & $c f l^{\mathrm{e}}$ & HrpZ $^{\mathrm{e}}$ & $\mathrm{NA}+{ }^{\mathrm{f}}$ & Pathog. ${ }^{g}$ \\
\hline 1 & Cutleaf geranium & Geranium dissectum & Candler, Tattnall, Toombs & Candler & $\mathrm{O}$ & 30 & 16.7 & 10.0 & 3.3 & 3.3 \\
\hline \multirow[t]{2}{*}{2} & Wild mustard & Brassica kaber & Candler, Tattnall, Toombs & Tattnall & $\mathrm{O}$ & 30 & 16.7 & 3.3 & 3.3 & 3.3 \\
\hline & & & & Toombs & $\mathrm{O}$ & & & & & \\
\hline 3 & Cutleaf evening primrose & Oenothera laciniata & Candler, Tattnall, Toombs & Candler & $\mathrm{F}$ & 30 & 43.3 & 20.0 & 16.7 & 16.7 \\
\hline 4 & Virginia pepperweed & Lepidium virginicum & Candler, Tattnall, Toombs & Toombs & $\mathrm{O}$ & 30 & 36.7 & 10.0 & 6.7 & 6.7 \\
\hline 5 & Black cherry & Prunus serotina & Candler, Tattnall, Toombs & Tattnall & $\mathrm{O}$ & 30 & 60.0 & 20.0 & 10.0 & 10.0 \\
\hline 6 & Soybean & Glycine $\max$ & Candler, Tattnall, Toombs & Candler & $\mathrm{O}$ & 30 & 60.0 & 26.7 & 10.0 & 10.0 \\
\hline \multirow[t]{3}{*}{7} & Italian rye grass & Lolium multiflorum & Candler, Tattnall, Toombs & Candler & $\mathrm{O}$ & 30 & 90.0 & 80.0 & 70.0 & 70.0 \\
\hline & & & & Tattnall & $\mathrm{F}$ & $\ldots$ & $\ldots$ & $\ldots$ & $\ldots$ & $\ldots$ \\
\hline & & & & Toombs & $\mathrm{O}$ & $\ldots$ & & & & \\
\hline \multirow[t]{3}{*}{8} & Curly dock & Rumex crispus & Candler, Tattnall, Toombs & Candler & $\mathrm{O}$ & 30 & 86.7 & 73.4 & 73.4 & 73.4 \\
\hline & & & & Tattnall & $\mathrm{N}$ & $\ldots$ & $\ldots$ & $\ldots$ & $\ldots$ & $\ldots$ \\
\hline & & & & Toombs & $\mathrm{O}$ & & & & & \\
\hline 9 & Pennsylvania smartweed & Polygonum pensylvanicum & Candler, Tattnall, Toombs & Tattnall & $\mathrm{N}$ & 30 & 13.3 & 10 & 6.7 & 6.7 \\
\hline 10 & Carolina geranium & Geranium carolinianum & Candler, Tattnall, Toombs & Toombs & $\mathrm{O}$ & 30 & 13.34 & 10.0 & 6.7 & 6.7 \\
\hline
\end{tabular}

a Sample collection site or county.

${ }^{\mathrm{b}}$ Site or county with positive sample.

${ }^{c}$ Field history. Samples were collected from perimeter of onion fields $(\mathrm{O})$ that had significant levels of yellow bud, from onion fields which were kept fallow for current year $(\mathrm{F})$, or from fields which were never used for onion production $(\mathrm{N})$

d Total number of samples collected.

${ }^{e}$ Polymerase chain reaction (PCR) conducted with $c f l$ - and HrpZ group IV-specific primers.

${ }^{\mathrm{f}}$ Isolation and recovery of Pseudomonas sp. on nutrient agar enriched with $0.5 \%$ yeast extract (NA+).

g Pathogenicity on onion; 15-day-old plants were injected with $1 \times 10^{8} \mathrm{CFU} / \mathrm{ml}$ and incubated for 15 days under greenhouse conditions of 25 to $28^{\circ} \mathrm{C}$ and 70 to $75 \%$ relative humidity. Seedlings were assayed for typical yellow bud symptoms (intense leaf-chlorosis).

Table 2. Number of samples in a 3-month survey (June, August, and September) in 2012 and 2013 of Italian ryegrass (Lolium multiflorum) and curly dock (Rumex crispus) that tested positive for the Pseudomonas sp. which causes yellow bud of onion

\begin{tabular}{|c|c|c|c|c|c|c|}
\hline \multirow[b]{3}{*}{ Year, zone ${ }^{b}$} & \multicolumn{6}{|c|}{ Positive $(\%)^{\mathbf{a}}$} \\
\hline & \multicolumn{2}{|c|}{ June } & \multicolumn{2}{|c|}{ August } & \multicolumn{2}{|c|}{ September } \\
\hline & Italian ryegrass & Curly dock & Italian ryegrass & Curly dock & Italian ryegrass & Curly dock \\
\hline \multicolumn{7}{|l|}{2012} \\
\hline $\mathrm{N}$ & 20 & 0 & 30 & 0 & $\mathrm{nf}$ & $\mathrm{nf}$ \\
\hline $\mathrm{S}$ & 50 & 40 & 20 & nf & 0 & 70 \\
\hline SW & 20 & 0 & $\mathrm{nf}$ & $\mathrm{nf}$ & 0 & 30 \\
\hline W & 10 & 0 & $\mathrm{nf}$ & 0 & 0 & 60 \\
\hline VOZ & 60 & 50 & 30 & 20 & 10 & 50 \\
\hline \multicolumn{7}{|l|}{2013} \\
\hline $\mathrm{N}$ & 10 & 0 & 40 & 0 & 0 & 60 \\
\hline $\mathrm{S}$ & 30 & 30 & 30 & 30 & 0 & 40 \\
\hline SW & 20 & 0 & $\mathrm{nf}$ & 0 & 0 & 30 \\
\hline W & 30 & 0 & nf & 0 & 0 & 30 \\
\hline VOZ & 70 & 20 & $\mathrm{nf}$ & 10 & 0 & 90 \\
\hline
\end{tabular}

${ }^{a}$ Percentage of Pseudomonas sp. positive samples out of 10 samples tested for each weed species at each locations; $\mathrm{nf}=$ not found.

${ }^{\mathrm{b}} \mathrm{N}=$ north, $\mathrm{S}=$ south, $\mathrm{W}=$ west, $\mathrm{SW}=$ southwest, and $\mathrm{VOZ}=$ Vidalia onion-growing zone. 
SW sampling sites because of recent mowing; however, samples could be collected at the other three locations. The percentage of Italian ryegrass samples that harbored the YB bacterium from the $\mathrm{N}, \mathrm{S}$, and within the VOZ sampling sites were 30,20 , and $30 \%$, respectively (Table 2). During the same sampling period, curly dock samples were present only at the VOZ site and the percentages of samples positive for the YB bacterium at these sites was $20 \%$. In September 2012, the bacterium was recovered from Italian ryegrass from only the $\mathrm{VOZ}$ site $(10 \%)$, whereas samples from the $\mathrm{S}, \mathrm{SW}$, and $\mathrm{W}$ sites were negative for the $\mathrm{YB}$ bacterium. Italian ryegrass samples were not found at the $\mathrm{N}$ sampling site during the September 2012 sampling period. In contrast, during the same period, higher percentages of curly dock sampled from $\mathrm{S}(70 \%)$, SW $(30 \%)$, W (60\%), and within the VOZ (50\%) sites harbored the Pseudomonas sp. responsible for YB. During the same period, curly dock samples were not found at the $\mathrm{N}$ sampling site.

In 2013, the YB bacterium was recovered from the Italian ryegrass at all sample sites, with percentages of positive samples at the N, W, SW, and S sites of 10,30, 20, and 30\%, respectively. Additionally, the percentage of positive Italian ryegrass samples at the VOZ site was $60 \%$ (Table 2). During the same period, curly dock samples were positive only at the S (30\%) and VOZ (20\%) sites. In August 2013, although Italian ryegrass samples were not found at the W, SW, and VOZ sites, samples from the N (40\%) and $\mathrm{S}(30 \%)$ sites were positive for the YB bacterium (Table 2). In contrast, during the same period, curly dock samples were present at all sample sites but the YB bacterium was recovered from the samples at the S (30\%) and VOZ (10\%) sites (Table 2). In September, none of the Italian ryegrass samples collected from different sample sites were positive for the YB bacterium whereas curly dock samples were recovered from $100 \%$ of the sample sites. The percentages of curly dock samples harboring epiphytic populations of the YB bacterium at the N,W, SW, S, and VOZ sites were 60, $30,30,40$, and $90 \%$, respectively (Table 2 ).

Seed transmission of Pseudomonas sp. Seed inoculated with PBS (negative control) did not develop YB symptoms after 14 days of incubation at $20^{\circ} \mathrm{C}$ under fluorescent lights. Regardless of isolation source, onion seed lots artificially inoculated with YB isolates resulted in YB incidence in 100\% of the seed lots tested; however, seed-to-seedling transmission percentages in individual lots varied (13.8 to $40.2 \%$ ). The mean seed germination percentages of seed lots inoculated with onion, Italian ryegrass, and curly dock isolates were 74,78 , and $83 \%$, respectively. For the same seed lots, mean seed-to-seedling transmission percentages of the YB bacterium were $78.4,50.5$, and $24.3 \%$, respectively.

Seedlings showing typical YB symptoms were used to make isolations. Colonies of the YB bacterium were observed as small (3 to $4 \mathrm{~mm}$ in diameter), cream-colored, flat colonies on NA+ medium. Subsequent identification was conducted using the LOPAT and icenucleation tests. Of the tested colonies, $100 \%$ were positive for levan production; negative for oxidase, potato rot, and arginine dihydrolase; produced hypersensitive reactions on tobacco; and were ice-nucleation active. In addition, DNA samples extracted from two colonies per plate were amplified with primers specific for the 16S rRNA and $c f l$ genes. Sequencing of the PCR products from onion, Italian ryegrass, and curly dock strains matched with the YB strain Pseudomonas sp. 7Y-1 (GenBank accession JF939841.1 [16S rRNA] and JF939842.1 [cfl]), P. syringae pv. atropurpurea (GenBank accession AB001440.1 [16S rRNA]), Pseudomonas sp. IRG-1 strain (GenBank accession KC786976.1 $[\mathrm{cfl}]$ ), and Pseudomonas sp. CD-1 strain (GenBank accession KC786977.1 [cfl]) (98 to $99 \%$ similarity with 16 s rRNA and 99 to $100 \%$ by $\mathrm{cfl}$ gene), respectively. However, pathogenicity of tested isolates on onion seedlings produced typical YB symptoms whereas seedlings inoculated with PBS remained asymptomatic at 15 days post inoculation.

\section{Discussion}

The identification of different sources of inocula is an important step in understanding the epidemiology of a disease and helps in devising strategies for its management. This study showed that the Pseudomonas sp. that causes $\mathrm{YB}$ can survive as an epiphyte on at least 10 different weed species in the VOZ of Georgia. The identified weeds included cutleaf geranium, wild mustard, cutleaf evening primrose, Virginia pepperweed, black cherry, soybean, Italian ryegrass, curly dock, Pennsylvania smartweed, and Carolina geranium. Among the positive weed species, the YB bacterium was recovered from more than $73 \%$ of the samples of Italian ryegrass and curly dock. Also, samples of these weeds were positive from all three sample sites, including a site adjacent to a fallow field where YB was first observed on onion 5 years earlier (in 2007). Although the host range of this Pseudomonas sp. is unknown, evidence provided by both PCR and recovery on NA+ medium suggest that common weeds may serve as asymptomatic hosts of epiphytic populations of bacteria (6).

Initial screening of weed samples by the $c f l$ gene- and HrpZ group IV-based PCR assays narrowed the number of samples for further processing to verify whether they harbored the YB bacterium. Viable colonies of the YB bacterium were recovered from subsamples that were positive by the PCR assay. The presumptive colonies were further identified as the YB pseudomonad by physiological tests, sequencing of the $16 \mathrm{~S}$ rRNA and $c f l$ genes, and pathogenicity on onion. Because the species of Pseudomonas sp. is unknown, PCR primers are unavailable; hence, the above procedure was used to identify bacteria from weed samples.

Because higher percentages of Italian ryegrass and curly dock samples were positive for the YB bacterium, these weeds were used as indicators to study the distribution and survival of the bacterium between onion crops (June, August, and September) for two consecutive years (2012 and 2013).The upright growth habit and height of the two weed species made it possible to locate them from a distance and made them suitable candidates for this study. Another advantage applicable to this study was that onion crops grown and marketed as Vidalia onion are restricted to a finite area established by Georgia law. As a result of this restriction, commercial onion crops are not produced outside of the VOZ. However, Italian ryegrass and curly dock are prevalent throughout the state $(5,17,19)$. YB was first reported in Tattnall County in 2007 (9); consequently, the monitoring of Italian ryegrass and curly dock around the boundaries of $\mathrm{VOZ}$ provided a unique opportunity to understand the spread and movement of the bacterium after its initial introduction. Our results suggest that the bacterium has moved outside the boundaries of the VOZ from its initial introduction site. This indicates that there is a potential risk of future spread of the pathogen to other onion-growing regions of the United States. Because we lack basic information on the biology and epidemiology of the pathogen, management of YB will be challenging.

Our data indicated that Italian ryegrass and curly dock can serve as a green bridge for the survival of Pseudomonas sp. between onion crops. However, survival of the YB bacterium on weeds varied from June to September in both years (2012 and 2013). In June 2012 and 2013, higher numbers of Italian ryegrass samples harbored epiphytic populations of the YB bacterium, with all sites having at least $10 \%$ of the samples that tested positive. In August for both years (2012 and 2013), at least $40 \%$ of the sample sites harbored the YB bacterium on Italian ryegrass whereas the weed samples were absent at the W and SW sites (2012 and 2013). Apparently, in June and, to some extent, in August, Italian ryegrass supported epiphytic populations of the YB bacterium whereas, in September, either due to phenological conditions of the weed or physiology of the bacterium, Pseudomonas sp. was detected on Italian ryegrass from only the VOZ sampling site in 2012. Although curly dock samples were present at all the sampling sites during June and August, with an exception (not found at the SW and S sampling sites in August 2012), the YB bacterium was recovered from only $40 \%$ of the sampling sites during these two months in both years (2012 and 2013). In contrast, the bacterium was recovered from $\geq 80 \%$ of the sites in September 2012 and 2013. This suggests that epiphytic populations of the YB bacterium 
survived better on curly dock in September than in June or August. The exact reason for the differential detection of the YB bacterium from Italian ryegrass and curly dock is unknown; however, it is possible that the observed results could be due to the phenology and survival of weeds at different times of the year. It is also possible that observed difference in epiphytic Pseudomonas sp. survival could be due to variation in environmental conditions (temperature, $\mathrm{RH}$, and precipitation) at different months of the year. For example, in the southeastern United States, Italian rye grass is prevalent from December to late June, whereas curly dock is prevalent from April to November $(17,19)$. Nevertheless, it is not clear if the presence or absence of the YB bacterium on these weeds at different times was due to preferences of the bacteria or the availability of the weed host. Future studies on the epiphytic fitness of the YB bacterium on these weeds should be done to answer some of the relevant questions.

Onion crops are harvested at mid-April and seedbeds are planted in September. The prevalence of higher percentages of the YB bacterium on curly dock compared with Italian ryegrass in September suggests that the former may be more likely to serve as a source of inoculum for onion seedlings. However, curly dock generally does not survive from November to February, indicating that it is less likely to serve as inoculum source for onion in production fields. In contrast, Italian ryegrass supporting epiphytic populations of the YB bacterium during the winter months (December to February) implicates it as a potential source of inoculum for onion in production fields. However, the exact epidemiological role of each weed species is still unknown and future studies are needed to examine their role on the epidemiology of YB in both seedbeds and production fields.

The ability of phytopathogenic bacteria to survive on weeds is common $(1,13,18)$. Schaad and Dianese (18) implicated seven cruciferous weeds as potential source of inoculum for Xanthomonas campestris pv. campestris in the seed and transplant production areas of California and Georgia, respectively. Similar to our study, cruciferous weeds collected by the authors were asymptomatic or had lesions which were not typical of black rot symptoms on cultivated cabbage. Nevertheless, X. campestris pv. campestris was widespread in these cruciferous weeds and, in some cases, the bacterium was recovered from weeds that were $30 \mathrm{~km}$ away from the nearest cultivated crops (18). In our case, the YB bacterium recovered on weeds from $\mathrm{N}, \mathrm{S}, \mathrm{SW}$, and $\mathrm{W}$ sites were approximately $60,90,92$, and $84 \mathrm{~km}$, respectively, away from the presumed original YB outbreak site in Tattnall County. Bacterial recovery from asymptomatic weeds was also demonstrated by Angeles-Ramos et al. (1) and Gent et al. (7). X. campestris pv. phaseoli and other pectolytic xanthomonads were isolated from symptomless weeds collected inside and adjacent to fields of dry edible bean (Phaseolus vulgaris) (1). Epiphytic X. axonopodis pv. allii was also recovered from the foliage of nine asymptomatic weed species and Medicago sativa in Colorado (7). In another study, McCarter et al. (13) recovered $P$. syringae pv. tomato from the foliage of asymptomatic chickweed (Stellaria media), henbit (Lamium amplexicaule), mouse ear cress (Arabidopsis thaliana), and evening primrose (Oenothera sp.) in a tomato field near Athens, GA. The authors indicated that $P$. syringae pv. tomato overwinters on these weeds, which serve as a source of inoculum for the spring-seeded tomato crops (13). In our case, we observed that the YB bacterium can also overseason on weeds (Italian ryegrass and curly dock) between onion crops and that the weeds can serve as inoculum sources for the onion in seed beds and production fields. Gitaitis et al. (10) reported that Pantoea ananatis, a causal agent of center rot of onion, can survive as an epiphyte on at least 25 different weeds species in the counties within and outside the $\mathrm{VOZ}$ in Georgia. In addition to weeds, the bacterium also was recovered from crop plants such as Bermuda grass (Cynodon dactylon), cowpea (Vigna unguiculata), and soybean (G. max). Similar to our study, they observed that some weeds such as Florida pusley supported epiphytic populations more consistently and, consequently, they used it as an indicator to monitor distribution of $P$. ananatis in the environment, much the way we used Italian ryegrass and curly dock.

Our seed transmission study with Pseudomonas sp. isolates from onion, Italian ryegrass, and curly dock showed that the bacterium can potentially be seed transmitted. However, seedling transmission of Pseudomonas sp. from naturally infested onion seed is yet to be determined. Additionally, despite the fact that YB strains from onion, Italian rye grass, and curly dock were pathogenic on onion, they differed in seed transmission rates. The exact reason for this phenomenon is unknown but future research should be conducted to study this aspect. In addition, the ability of Pseudomonas sp. isolates to transmit YB from artificially infested seed suggests that weeds can potentially serve as reservoirs for the epiphytic YB bacterium populations that can be seed transmitted. Nevertheless, the results indicated that onion seed can be a potential source of inoculum for development of YB. Hence, further research is required to determine the epidemiological significance of seedborne inoculum and efficient methods to eliminate this threat to onion production in Georgia.

In conclusion, we demonstrated that the YB bacterium could survive as an epiphyte on weeds in southern Georgia. This implicates weeds as a possible source of inoculum for YB outbreaks in onion. In addition, our data indicated the bacterium could be seedborne. Consequently, the presence of multiple sources of inocula will make it more difficult to develop control strategies against the YB bacterium, because both seed and weeds will have to be targeted for exclusion and eradication of the pathogen.

\section{Acknowledgments}

This study is a part of the project supported by Vidalia Onion Commission (grant number 2521RF-332621). We thank T. Brenneman, Professor at the University of Georgia, Tifton for his helpful critique of the manuscript.

\section{Literature Cited}

1. Angeles-Ramos, R., Vidaver, A. K., and Flynn, P. 1991. Characterization of epiphytic Xanthomonas campestris pv. phaseoli and pectolytic xanthomonads recovered from symptomless weeds in the Dominican Republic. Phytopathology 81:677-681.

2. Bender, C. L., Liyanage, H., Palmer, D., Ullirich, M., Young, S., and Mitchell, R. 1993. Characterization of the genes controlling the biosynthesis of the polyketide phytotoxin coronatine including conjugation between coronafacic and coronamic acid. Gene 133:31-38.

3. Bender, C. L., Stone, H. E., Sims, J. J., and Cooksey, D. A. 1987. Reduced pathogen fitness of Pseudomonas syringae pv. tomato Tn5 mutants defective in coronatine production. Physiol. Mol. Plant Pathol. 30:273-283.

4. Bereswill, S., Bugert, P., Volksch, B., Ullrich, M., Bender, C. L., and Gieder K. 1994. Identification and relatedness of coranatine producing Pseudomonas syringae pathovars by PCR analysis and sequence determination of the amplification product. Appl. Environ. Microbiol. 60:2924-2930.

5. Duncan, W. H., and Kartesz, J. T. 1981. Vascular Flora of Georgia. The University of Georgia Press, Athens.

6. Dutta, B., Gitaitis, R. D., Lewis, K. L., Booth, C., Langston, D. B., Webster, T. M., Riner, C. M., and Edenfield, J. D. 2013. New report of Lolium multiflorum L. and Rumex crispus L. as resident weed hosts of epiphytic populations of Pseudomonas sp., causal agent of yellow bud in onions in Georgia, U.S.A. New Dis. Rep. 27:18.

7. Gent, D. H., Lang, J. M., Bartolo, M. E., and Schwartz, H. F. 2005. Inoculum sources and survival of Xanthomonas axonopodis pv. allii in Colorado. Plant Dis. 89:507-514.

8. Gerhardt, P., Murray, R. G. E., Costilow, R. N., Nester, E. W., Wood, W. A., Krieg, N. R., and Phillips, G. B., eds. 1981. Manual of Methods for General Bacteriology. American Society for Microbiology, Washington, DC.

9. Gitaitis, R., Walcott, R., Culpepper, S., Sanders, H., Zolobowska, L., and Langston D. 2002. Recovery of Pantoea ananatis, causal agent of center rot of onion, from weeds and crops in Georgia, USA. Crop Prot. 21:983-989.

10. Gitaitis, R. D., Mullis, S., Lewis, K., Langston, D., Watson, A. K., Sanders, H., Torrance, R., Jones, J. B., and Nischwitz, C. 2012. First report of a new disease of onion in Georgia caused by a non-fluorescent Pseudomonas sp. Plant Dis. 96:285

11. Inoue, Y., and Takikawa, Y. 2006. The hrpZ and $h r p A$ genes are variable, and useful for grouping Pseudomonas syringae bacteria. J. Gen. Plant Pathol. 72:26-33.

12. Lelliot, R. A., Billing, E., and Hayward, A. C. 1966. A determinative scheme for the fluorescent plant pathogenic pseudomonads. J. Appl. Bacteriol. 29:470-489.

13. McCarter, S. M., Jones, J. B., Gitaitis, R. D., and Smitley, D. R. 1983. Survival of Pseudomonas syringae pv. tomato in association with tomato seed, soil, host tissue, and epiphytic weed hosts in Georgia. Phytopathology 
73:1393-1398.

14. Mitchell, R. E. 1982. Coronatine production by some phytopathogenic pseudomonads. Physiol. Plant Pathol. 20:83-89.

15. Mitchell, R. E., and Young, H. 1978. Identification of a chlorosis inducing toxin of Pseudomonas glycinea as coronatine. Phytochemistry 17:20282029.

16. Mitchell, R. E., Young, S. A., and Bender, C. L. 1993. Coronamic acid, an intermediate in coronatine biosynthesis by Pseudomonas syringae. Phytochemistry 35:343-348.

17. Radford, A. E., Ahles, H. E., and Bell, C. R. 1964. Manual of the Vascular Flora of the Carolinas. The University of North Carolina Press, Chapel Hill.

18. Schaad, N. W., and Dianese, J. C. 1981. Cruciferous weeds as sources of inoculum of Xanthomonas campestris in black rot of crucifers. Phytopathology 71:1215-1220.

19. Stucky, J. M. 1980. Identifying seedling and mature weeds common in the southeastern United States. Bull. No. 461. North Carolina Agricultural Research Service and the North Carolina Cooperative Extension Service, North Carolina State University, Raleigh.

20. Volksch, B., Bublitz, F., and Fritsche, W. 1989. Coronatine production by Pseudomonas syringae pathovars: screening method and capacity of product formation. J. Basic Microbiol. 29:463-468.

21. Weisburg, W. G., Barns, S. M., Pelletier, D. A., and Jane, D. J. 1991. 16S ribosomal DNA amplification for phylogenetic study. J. Bacteriol. 173:697703. 